\title{
Lato, Koronawirus i zespół suchego oka - skuteczne metody leczenia
}

\author{
Summer, coronavirus and dry eye syndrome- \\ effective treatments
}

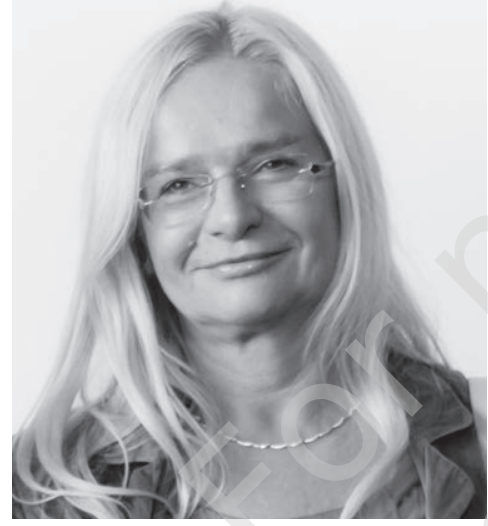

N A JW A Ż N IE JSZE

Pomimo pandemii COVID-19 nie wolno zapomnieć, że istnieją też inne choroby, takie jak zespół suchego oka, który może znacznie utrudniać życie pacjentów.

\section{H I G H L I G H T S}

Despite the coronavirus pandemic, one should not forget that there are other diseases, such as dry eye syndrome, which can significantly impending patients' lives.

\section{Marta Misiuk-Hojło ${ }^{1}$, Grzegorz Jasina ${ }^{2}$ \\ ${ }^{1}$ Katedra i Klinika Okulistyki, Uniwersytet Medyczny im. Piastów Śląskich we Wrocławiu Kierownik Katedry i Kliniki: prof. dr hab. n. med. Marta Misiuk-Hojło ${ }^{2}$ Szpital Specjalistyczny im. Stefana Żeromskiego w Krakowie Kierownik: dr n. med. Małgorzata Woś}

\section{STRESZCZENIE}

Od grudnia pandemia COVID-19 dotyka wiele osób. Dzisiaj żyjemy w innej rzeczywistości. Jednak mimo śmiertelnego zagrożenia dalej musimy nieść pomoc pacjentom z rozmaitymi problemami medycznymi. Często do gabinetu okulistycznego trafiają osoby z zespołem suchego oka. Zwykle nie jest to poważna komplikacja, jednak może dotkliwie utrudniać życie pacjentów, a w wyjątkowych sytuacjach zrujnować ich widzenie. W pracy zostaną przedstawione objawy zespołu suchego oka, jego przyczyny, a także skuteczne metody leczenia. Omówiono również problem COVID-19 jako jednostki chorobowej, objawy oczne, które może powodować, oraz częstość występowania objawów okulistycznych u osób z tą chorobą. Ponadto opisany został związek między koronawirusem a zespołem suchego oka.

Słowa kluczowe: koronawirus, lato, zespół suchego oka

\section{ABSTRACT}

Since December, the COVID-19 pandemic has been affecting many people. Today we live in a different reality. However, despite the lethal threat, we still need to help patients with various medical problems. Often people with dry eye syndrome visit the ophthalmology' consulting room. It's usually not a serious complication, but it can severely hinder patients' lives and, in exceptional cases, ruin their vision. The article will present the symptoms of dry eye syndrome, causes and effective treatments. There are also discussed: the problem of COVID-19 as a disease entity, ocular symptoms whom may cause and the incidence of eye symptoms among people with this disease. In addition it will be described the connection between coronavirus and dry eye syndrome.

Key words: coronavirus, summer, dry eye syndrome 


\section{WSTĘP}

Tegoroczne lato przynosi nam wszystkim szereg wyzwań. I dotyczy to nie tylko okulistów, ale i innych lekarzy, zwłaszcza praktyków. Z powodu pandemii COVID-19 chwilowo zatrzymano gospodarkę. W służbie zdrowia również wstrzymano przyjmowanie pacjentów niewymagających pilnej pomocy. Wszystko to miało na celu ograniczenie rozprzestrzeniania się wirusa. Obecnie (połowa czerwca 2020 r.) obserwujemy spłaszczanie się krzywej epidemiologicznej nowych zachorowań. Powoli wracamy do normalności. Powracają do nas pacjenci cierpiący nie tylko na poważne choroby, w tym COVID-19.

Niezaprzeczalnie groźną konsekwencją pandemii jest przełożenie znacznej liczby wizyt pacjentów ambulatoryjnych na późniejsze terminy. Pomoc zostanie im udzielona z nawet 3-miesięcznym opóźnieniem. Ponieważ nie są to przypadki nagłe, dłuższy czas oczekiwania nie powinien wpłynąć na stan zdrowia pacjentów. Teoretycznie. Należy się zastanowić, co w przypadkach, kiedy pacjent nie odczuwa dolegliwości, a jego stan miejscowy ulega pogorszeniu. Wizyta wraz z badaniem w zaistniałej sytuacji nie zostanie zrealizowana, a rozpoznanie ustalone. Pacjent rozpocznie leczenie dopiero po dłuższym czasie.

Innym następstwem epidemii jest mniejsza dostępność pomocy specjalistycznej. W ostatnich miesiącach wiele gabinetów lekarskich zostało czasowo zamkniętych, szczególnie w małych miejscowościach. Pacjenci z takich lokalizacji musieli w stanach nagłych zgłaszać się do ośrodka oddalonego od ich miejsca zamieszkania. Bardzo często skutkowało to otrzymaniem przez pacjenta pomocy z dużym opóźnieniem.

Nie możemy też zapomnieć o sytuacji lekarzy i pacjentów w poradniach, w których nie odbywały się teleporady. Tam okres oczekiwania na konsultacje znacznie się wydłużył. Po powrocie do dawnych grafików trudno przyjąć wszystkich obecnych chorych oraz tych, których wizyty zostały przełożone. Często koliduje to z dostępnością gabinetu czy czasu pracy specjalisty.

Trzeba też mieć na uwadze, że zbliża się okres urlopowy. Naturalne jest to, iż potrzebujemy wypoczynku. Część z nas już dawno zaplanowała wakacyjny wyjazd. Co zrobić w zaistniałej sytuacji? Przełożyć, bo mamy kolejki pacjentów? Wyjechać, bo potrzebujemy odpoczynku po ostatnich intensywnych miesiącach? Niewątpliwie mamy do czynienia z ogromnym dysonansem.

Spoglądając na wskazane powyżej aspekty, możemy być pewni, że czeka nas burzliwy okres. Pandemia trwa nadal, codziennie przybywa nowych zachorowań. A jednocześnie wracamy do wcześniejszego trybu pracy. Czego możemy się spodziewać? Z pewnością bardziej wymagających, trudnych, ale też często zaniedbanych pacjentów. Obcowania z niemalejącym strachem. A także ciągłego wzmożonego rygoru sanitarnego.
Wydawać by się mogło, że pandemia COVID-19 nie wpłynie na pacjentów okulistycznych. Jednak już dzisiaj mamy świadomość, że może mieć na nich ogromny wpływ. Warto się zastanowić, jak oddziałuje ona na pacjentów z zespołem suchego oka, u których w szczególnych przypadkach odroczenie leczenia może się okazać bardzo groźne.

\section{ZESPÓŁ SUCHEGO OKA}

Jak dobrze wiemy, zespół suchego oka jest schorzeniem związanym ze zmniejszeniem wydzielania łez bądź też z zaburzeniem ich składu. Skutkuje to nieprawidłową strukturą filmu łzowego, a w konsekwencji objawami u pacjenta.

Sam film łzowy składa się z trzech warstw: warstwa lipidowa, wydzielana przez gruczoły Meiboma; warstwa mucynowa (śluzowa), wydzielana w większości przez wydzielinę komórek kubkowych spojówki, oraz warstwa wodna, tworzona przez wydzielinę gruczołów łzowych.

Natomiast prosty podział zespołu suchego oka wynika z klasyfikacji DEWS z 2007 r. i opiera się na patofizjologii schorzenia. Wyróżniamy postacie: związaną z niedoborem warstwy wodnej, związaną z nadmiernym parowaniem łez oraz mieszaną.

Zgodnie z danymi epidemiologicznymi zespół suchego oka dotyka 6,8\% dorosłej populacji Stanów Zjednoczonych (ok. 16,4 mln osób) [1]. Inne badania podają, że mówimy tu o $5,5 \%$ do nawet $57,1 \%$ populacji na świecie [2]. Ryzyko zachorowania wzrasta wraz $\mathrm{z}$ wiekiem i jest wyższe u kobiet niż u mężczyzn. W patofizjologii powstawania zespołu suchego oka należy wymienić: hiperosmolarność i niestabilność filmu łzowego, uszkodzenie powierzchni oka oraz stan zapalny. Zapalenie spojówek, powierzchni oka i gruczołów dodatkowych może być zarówno konsekwencją, jak i przyczyną zespołu suchego oka; m.in. dysfunkcja gruczołów Meiboma, która skutkuje ubytkiem składowych lipidowych w filmie łzowym, co sprzyja występowaniu zjawiska nadmiernego parowania.

Wśród przyczyn choroby wyróżniamy: zaawansowany wiek, płeć żeńską, zaburzenia hormonalne (szczególnie obniżenie stężenia androgenów), choroby ogólne (cukrzycę, chorobę Parkinsona, zespół Sjögrena), niską wilgotność środowiska, przebyte operacje okulistyczne (szczególnie chirurgię refrakcyjną), obniżenie czucia rogówki, niedobór witamin (np. witaminy A), stosowanie zawierających konserwanty leków do oczu, noszenie soczewek kontaktowych, leki stosowane ogólnie (przeciwhistaminowe, antycholinergiczne, estrogeny, izotretynoina, amiodaron, kwas nikotynowy).

Zazwyczaj zgłaszanym przez pacjentów objawem choroby jest łagodny do umiarkowanego dyskomfort [3]. Pozostałe objawy to: uczucie ciała obcego, ogólne podrażnienie, uczucie suchości, zaczerwienienie oczu, uczucie piasku pod powieką, paradoksalne łzawienie, wrażliwość na świa- 
tło i zamazane widzenie. Objawy ulegają zaostrzeniu z powodu stosowanych leków, wietrznej pogody, zimna oraz niskiej wilgotności. Istotna jest niewielka korelacja między objawami a stanem miejscowym [4]. Ma to szczególne znaczenie w przypadku braku regularnych kontroli okulistycznych.

W badaniu okulistycznym zazwyczaj obserwujemy tylne łojotokowe zapalenie brzegów powiek i zaczerwienienie spojówki. Zdarza się nawet jej zwiotczenie. W filmie łzowym stwierdzamy obecność cząsteczek i tkanek, które przesuwają się przy mruganiu, a menisk brzeżny zanika bądź staje się cieńszy. Rogówka ma zazwyczaj punktowate ubytki nabłonka barwiące się fluoresceiną. Na jej powierzchni znajdują się filamenty złożone z nitek śluzu i komórek nabłonka. Wyżej wymienione standardowe objawy zazwyczaj nie prowadzą do stałego uszkodzenia wzroku, jednak istnieją powikłania takie jak: niewydolność nabłonka, bakteryjne zapalenie rogówki, jej malacja i perforacja, które są już poważnymi stanami okulistycznymi, wymagającymi pilnej interwencji lekarza specjalisty.

Wedle wytycznych DEWS leczenie opiera się na wybraniu odpowiedniego stopnia ciężkości choroby u danego pacjenta: w skali od 1 do 4 . Jeżeli zalecenia z wybranego przez nas poziomu nie pomagają, należy przejść do poziomu następnego. Stopień I opiera się na modyfikacji warunków środowiska, diety oraz edukacji. Powinno się tu ocenić, czy leki stosowane ogólnie przez pacjenta nie wpływają na suchość oczu. Poza tym należy zająć się higieną brzegów powiek, a w razie potrzeby przeprowadzić operację okuloplastyczną. W tym punkcie włączamy leczenie nawilżające w postaci kropli, żelu lub maści. Stopień II polega na stosowaniu sztucznych łez bez konserwantów, miejscowo leków przeciwzapalnych, ogólnie tetracyklin, zatyczek punktów łzowych, komór wilgotnych oraz pobudzenia wydzielania łez za pomocą leków ogólnych (np. pilokarpiny). W tym punkcie zaleca się również stosowanie doustnej suplementacji kwasami omega. Jednak co do tego zalecenia nie ma pełnej zgodności $[5,6]$. Postępowanie w stopniu III polega na stosowaniu kropli z surowicy krwi, soczewek kontaktowych i trwałej okluzji punktów łzowych. W stopniu IV stosuje się ogólne leki przeciwzapalne i zabiegi chirurgiczne typu tarsorafia, przeszczep gruczołów ślinowych, naszycie owodni. Nowsze metody leczenia zespołu suchego oka oparte są na stosowaniu zabiegów laserowych związanych z intensywnym pulsem światła (IPL, intensive pulse light), podczas których wiązka lasera jest absorbowana, skutkiem czego złogi tłuszczowe w gruczołach Meiboma są upłynniane. Powadzi to do oczyszczenia przewodów wydzielniczych i w efekcie do poprawy warstwy tłuszczowej filmu łzowego. Podobna zasada występuje w zabiegach z wykorzystaniem urządzenia LipiFlow ${ }^{\ominus}$ Thermal Pulsation System. Urządzenie rozpuszcza złogi tłuszczowe, które następnie są usuwane za pomocą specjalnej mechanicznej końcówki.
W efekcie poprawiamy jakość składowej warstwy tłuszczowej filmu łzowego. Warto jeszcze wspomnieć o nowości, którą jest kwantowy rezonans komórkowy, zarówno upłynniający złogi tłuszczowe gruczołów Meiboma, jak i wpływający na poziomie komórkowym na inne gruczoły biorące udział w utrzymywaniu prawidłowego składu łez (komórki kubkowe spojówki, gruczoł łzowy, Molla, Zeissa, Henlego i Mainza, Krausego i Wolfringa) [7].

Szczególną opieką należy otoczyć pacjentów z neuropatią cukrzycową, gdyż to właśnie oni, z powodu nieporównywalnie mniejszej wrażliwości na ból, mogą o wiele częściej zgłaszać się z poważnymi objawami okulistycznymi. Podobnie dzieje się wśród pacjentów po laserowej korekcji wzroku (zabieg LASIK), u których spotykamy się z pooperacyjnym obniżeniem czucia rogówkowego.

Najpopularniejszą metodą leczenia jest stosowanie kropli nawilżających. Jednakże jeśli pacjent stosuje krople częściej niż cztery razy dziennie, preferowane jest używanie środków bez konserwantów [8]. Kiedy krople nie wystarczają, warto przemyśleć stosowanie żelu bądź maści.

Jeśli najprostsze metody nie są efektywne, należy zastanowić się nad wdrożeniem innych leków. W leczeniu warto zastosować miejscowo cyklosporyny. To bezpieczny i dobrze tolerowany lek. Nie jest jednak jasne, czy przynosi klinicznie istotne korzyści dla pacjenta [9, 10]. Zazwyczaj stosuje się 0,05\% emulsje i 0,09\% roztwory. Leczenie może trwać nawet do 6 tygodni albo dłużej, zanim pacjent odczuje poprawę. Innym lekiem stosowanym miejscowo jest $5 \%$ roztwór lifitegrastu - antagonisty integryn. Stosuje się go dwa razy dziennie. Zmniejsza on uwalnianie cytokin i ogranicza dalszą rekrutację komórek T. W krótkim terminie ulgę pacjentowi mogą przynieść miejscowo podawane glikokortykosteroidy $[11,12]$. Nie zapominajmy jednak, że ich przewlekłe przyjmowanie wiąże się z licznymi działaniami niepożądanymi.

Udowodniono, że stosowanie doustnych antyoksydantów przynosi korzyści w leczeniu pacjentów z zespołem suchego oka. U pacjentów, którzy otrzymywali witaminy $E, B_{2}$ i C oraz cynk i selen, odnotowano dłuższy czas przerwania filmu łzowego, lepszy wynik testu Schirmera oraz zmniejszenie nasilenia objawów [13].

Warto jeszcze wspomnieć, że obecnie trwają badania nad dikwafosolem [14] i rebamipidem [15], które weryfikują skuteczność tych substancji w leczeniu objawów suchego oka.

\section{KORONAWIRUS}

SARS-CoV-2 jest wirusem osłonkowym, o genomie zbudowanym z jednoniciowego RNA o dodatniej polarności. Powoduje on chorobę zwaną COVID-19. Wirus ten został wykryty w wydzielinie $\mathrm{z}$ nosa, gardła, ślinie, kale, łzach i krwi. Obecnie za źródła zakażenia uznaje się jamę ustną, 
jamę nosową, a także powierzchnię oka [16]. COVID-19 jest wysoce zaraźliwą chorobą zdolną do progresji w zespół ostrej niewydolności oddechowej, która może doprowadzić do śmierci [17].

\section{Koronawirus a schorzenia okulistyczne}

Wirus może powodować surowicze zapalenie spojówek u ludzi. W literaturze nie ma potwierdzonych innych wywołanych przez niego schorzeń oka. U kotów i myszy koronawirusy powodują zapalenie spojówek, zapalenie błony naczyniowej przedniego odcinka gałki ocznej, zapalenie siatkówki i zapalenie nerwu wzrokowego [18].

Zapalenie spojówek występujące w wyniku COVID-19 to choroba samoograniczająca się, niewymagająca specjalnego leczenia. Wystarczające jest leczenie objawowe [19]. W literaturze opisuje się leczenie zapalenia za pomocą kropli z rybawiryną [17] bądź gancyklowirem [20]. Często badacze skupiają się na pobieraniu wymazów z worka spojówkowego, który jest traktowany jako potencjalna droga zakażenia. Diagnoza opiera się na metodzie RT-PCR [17]. Wyniki tych badań pokazują jednak, że obecność wirusa w wymazie ze spojówki stwierdza się zazwyczaj u nielicznego procenta zarażonych, szczególnie u osób, które nie prezentują objawów ocznych.

Występowanie objawów okulistycznych wykazały również chińskie badania nad SARS-CoV-2. Spośród 102 pacjentów z objawami COVID-19, zmianami w rentgenie i tomografii klatki piersiowej, u 72 potwierdzono obecność wirusa. Tylko u dwóch pacjentów stwierdzono zapalenie spojówek, $\mathrm{w}$ tym tylko u jednego wykazano obecność RNA wirusa

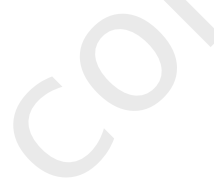

ADRES DO KORESPONDENCJ

prof. dr hab. n. med. Marta Misiuk-Hojło

Katedra i Klinika Okulistyki,

Uniwersytet Medyczny im. Piastów Śląskich we Wrocławiu

50-556 Wrocław, ul. Borowska 213

e-mail: marta.misiuk-hojlo@umed.wroc.pl w worku spojówkowym [20]. Warto wiedzieć, że zapalenie spojówek zazwyczaj nie jest pierwszym objawem choroby COVID-19. Występuje zwłaszcza u pacjentów z jej cięższą manifestacją bądź ze szczególnymi zaburzeniami w badaniach laboratoryjnych krwi [21].

\section{Koronawirus a zespół suchego oka}

Pozornie wydaje się, że koronawirus nie ma związku z zespołem suchego oka. Jednakże wywołując zapalenie spojówek, zwiększa komponentę zapalną w patofizjologii zespołu suchego oka. Warto też się zastanowić, czy osłabione mechanizmy obronne przedniego odcinka spowodowane suchym okiem nie ułatwiają wnikania wirusa do organizmu. Badacze udowodnili, że niektóre wirusy z rodziny Coronaviridae mają powiązanie ze schorzeniami neurologicznymi. Zbadane przykłady powikłań neurologicznych [22, 23] nie mają bezpośredniego związku z wirusem SARS-CoV-2. Jednak można przypuszczać, że w jego przypadku związek ten również zachodzi. Wpływ zaburzeń neurologicznych na przebieg zespołu suchego oka jest oczywisty.

\section{PODSUMOWANIE}

Epidemia COVID-19 zdominowała świat medyczny. Niejako zapomnieliśmy o innych chorobach. One jednak nadal występują i wymagają leczenia. Jako lekarze musimy o tym pamiętać, a szczególną uwagę zwrócić na jednostki chorobowe, które pozornie wydają się łagodne, takie jak zespół suchego oka.

\section{ORCID}

Marta Misiuk-Hojło - ID - http://orcid.org/0000-0002-4020-3203 Grzegorz Jasina - ID - http://orcid.org/0000-0002-5481-8436 


\section{Piśmiennictwo}

1. Farrand KF, Fridman M, Stillman IÖ et al. Prevalence of Diagnosed Dry Eye Disease in the United States Among Adults Aged 18 Years and Older. Am J Ophthalmol. 2017; 182: 90-8.

2. Ambroziak AM. Ciężki zespół suchego oka - epidemiologia i klasyfikacja na podstawie aktualnych wytycznych Oddisey Algorytm. Okulistyka. 2014; 25(1).

3. Satitpitakul V, Kheirkhah A, Crnej A et al. Determinants of Ocular Pain Severity in Patients With Dry Eye Disease. Am J Ophthalmol. 2017; 179: 198-204.

4. Nichols KK, Nichols JJ, Mitchell GL. The lack of association between signs and symptoms in patients with dry eye disease. Cornea. 2004; 23(8): 762-70.

5. Bhargava R, Kumar P. Oral omega-3 fatty acid treatment for dry eye in contact lens wearers. Cornea. 2015; 34: 413-20.

6. Dry Eye Assessment and Management Study Research Group, Asbell PA, Maguire MG et al. n-3 Fatty Acid Supplementation for the Treatment of Dry Eye Disease. N Engl J Med. 2018; 378: 1681-90.

7. Fryczkowski P. Leczenie zespołu suchego oka za pomocą kwantowego rezonansu komórkowego. OphthaTherapy. 2020; 1: 66-9.

8. Jones L, Downie LE, Korb D et al. TFOS DEWS II Management and Therapy Report. Ocul Surf. 2017; 15(3): 575-628.

9. de Paiva CS, Pflugfelder SC, Ng SM et al. Topical cyclosporine a therapy for dry eye syndrome. Cochrane Database Syst Rev. 2019; 9(9): CD010051. https://doi.org/10.1002/14651858.CD010051.pub2.

10. Malta JB, Soong HK, Shtein RM et al. Treatment of ocular graft-versus-host disease with topical cyclosporine $0.05 \%$. Cornea. 2010; 29(12): 1392-96.

11. Avunduk AM, Avunduk MC, Varnell ED et al. The comparison of efficacies of topical corticosteroids and nonsteroidal anti-inflammatory drops on dry eye patients: a clinical and immunocytochemical study. Am J Ophthalmol. 2003; 136(4): 593-602.

12. Pinto-Fraga J, López-Miguel A, González-García MJ et al. Topical Fluorometholone Protects the Ocular Surface of Dry Eye Patients from Desiccating Stress: A Randomized Controlled Clinical Trial. Ophthalmology. 2016; 123(1): 141-53.

13. Drouault-Holowacz S, Bieuvelet S, Burckel A et al. Antioxidants intake and dry eye syndrome: a crossover, placebo-controlled, randomized trial. Eur J Ophthalmol. 2009; 19(3): 337-42.

14. Shigeyasu C, Hirano S, Akune $Y$ et al. Diquafosol Tetrasodium Increases the Concentration of Mucin-like Substances in Tears of Healthy Human Subjects. Curr Eye Res. 2015; 40(9): 878-83.

15. Ueda K, Matsumiya W, Otsuka K et al. Effectiveness and relevant factors of $2 \%$ rebamipide ophthalmic suspension treatment in dry eye. BMC Ophthalmol. 2015; 15: 58.

16. Prost ME. Koronawirus a narząd wzroku. Możliwości zakażenia, objawy kliniczne i profilaktyka w gabinecie okulistycznym. OphthaTherapy. 2020; 25(1): 5-9.

17. Chen L, Liu M, Zhang Z et al. Ocular manifestation of a hospitalized patient with confirmed 2019 novel coronavirus disease. BJ Ophthalmol. 2020; 104(6): 748-51.

18. Seah I, Agrawal R. Can the Coronavirus Disease 2019 (COVID-19) Affect the Eyes? A Review of Coronaviruses and Ocular Implications in Humans and Animals. Ocul Immunol Inflamm. 2020: 1-5. https://doi.org/10.1080/09273948.2020.1738501.

19. Hu K, Patel J, Patel BC. Ophthalmic Manifestation of Coronavirus (COVID-19). StatPearls Publishing 2020.

20. Sun $X$, Zhang $X$, Chen $X$ et al. The infection evidence of SARS-COV-2 in ocular surface: single-center cross-sectional study. medRxiv 2020. htps://doi.org/10.1101/2020.02.26.20027938.

21. Wu P, Duan F, Luo C et al. Characteristics of Ocular Findings of Patients with Coronavirus Disease 2019 (COVID-19) in Hubei Province, China. JAMA Ophthalmol. 2020; 138(5): 575-8.

22. Jacomy H, Talbot PJ. Vacuolating encephalitis in mice infected by human coronavirus OC43. Virology. 2003; 315(1): 20-33.

23. Yeh EA, Collins A, Cohen ME et al. Detection of coronavirus in the central nervous system of a child with acute disseminated encephalomyelitis. Pediatrics. 2004; 113(1): e73-e76. https://doi.org/10.1542/peds.113.1.e73.

Konflikt interesów:

Nie występuje.

Finansowanie:

Nie występuje.

Etyka:

Treści przedstawione w artykule są zgodne z zasadami Deklaracji Helsińskiej,

dyrektywami EU oraz ujednoliconymi wymaganiami dla czasopism biomedycznych.
Conflict of interest:

None.

Financial support:

None.

Ethics:

The content presented in the article complies with the principles of the Helsinki Declaration, EU directives and harmonized requirements for biomedical journals. 